\title{
呼吸器感染症に対する Cefoxitin の臨床評価
}

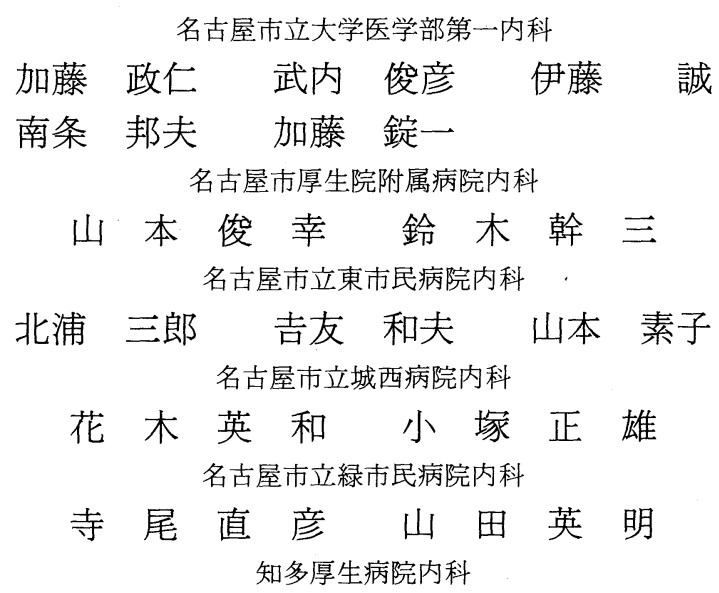

横 地潔奥 山 悦 郎

愛知県立尾張病院内科

永坂 博 彦

（昭和 58 年 2 月 10 日受付）

(昭和58年 3 月 1 日受理)

要旨

Cefoxitin を各種呼吸器感染症66例（効果判定対象55例，副作用判定対象63例）に使用し，次のような 結果を得た.

1. 55 例中有効以上と判定した症例は 42 例（76.4\%）であった.

2. 呼吸器感染症の種類別での有効率は, 一次性肺炎では $84.6 \%$, 二次性肺炎では $68.8 \%$, 慢性気道感 染症急性増悪では $69.2 \%$ あっった。

3. 重症度別臨床効果は, 軽症では $90.9 \%$, 中等症では $76.3 \%$, 重症では $50.0 \%$ 有効率であった。

4. 年齢別臨床効果は， 69 歳以下では $82.8 \% ， 70$ 歳以上では $69.2 \%$ の有効率であった。

5. 原因菌が検出できた 13 例での細菌学的効果は, 消失 10 例, 減少 1 例, 菌交代 2 例であった。 また, 常在菌からの菌交代が 2 例に認められた。交代菌はP. aeruginosa ( 2 例), E. agglomerans ( 1 例), K. pneumoniae ( 1 例) であった.

6. 他剂無効例（11例）に対しては，有効が 7 例（63.6\%）であった。

7. 本剂無効の 3 例では minocycline, ceftizoxime, cefotaximeのそれぞれが有効であった.

8. 副作用は 8 例にみられ, 発疹 1 例, GOT 上昇 2 例, GOT $\cdot$ BUN 上昇 1 例, BUN $\cdot$ creatinine 上 昇 1 例, Al-p 上昇 1 例，白血球減少 2 例であったが，本剤中止後すみやかに正常に復した.

\section{緒言}

Cefoxitin（マーキシン注射用，以下 CFX と略 す）は1972年，米国 Merck Sharp \& Dohme

別刷請求先：（尔467）名古屋市瑞穂区瑞穂町字川澄 1 名古屋市立大学医学部第一内科

加藤 政仁
Research Laboratoriesに执いて開発されたcephamycin 系抗生物質である ${ }^{1)}$. その抗菌力はグラ ム陽性菌のみならず， $\beta$-lactamase に対して強い 抵抗性を示すこととから, 他剂耐性 E. coliをはじ め, Klebsiella, indole 陽性 Proteus, Serratia など のグラム陰性桿菌や Bacteroides fragilis などの 
Table 1 Collaborating clinics

The First Department of Internal Medicine, Nagoya City University,
School of Medicine
Nagoya Koseiin Geriatric Hospital
Department of Internal Medicine, Nagoya Higashi Municipal Hospital
Department of Internal Medicine, Nagoya City Johsai Hospital
Department of Internal Medicine, Nagoya Midori Municipal Hospital
Department of Internal Medicine, Chita General Hospital
Department of Internal Medicine, Owari Prefectural Hospital

嫌気性菌にも抗菌力を示している(2)-4).

ヒトに静注した場合の血中半減期は抌よそ30分 と比較的短く，体内で葟とんど代謝されることな く尿中に高濃度で排出される5).

本剂に関してはすでに多くの研究がなされ第25 回日本化学療法学会総会において検討評価が行わ れて和り，呼吸器感染症を含む各科領域の感染症 に対し高い臨床効果が認められている5).

今回，私共は本剂の有効性，安全性などを検討 するため, 一次性肺炎, 二次性肺炎, 慢性気道感 染症急性増悪の 3 群の呼吸器感染症を対象として Table 1 に示した 7 施設に掞いて, 昭和56年12月 から昭和57年 3 月にわたって臨床治験を実施し た。 以下その成績について報告する。

\section{方 法}

\section{I 研究対象}

\section{1. 対象患者}

入院患者を対象とし，年齢は16歳以上の成人で 性別は不問とした。

\section{2. 対象疾患}

急性肺炎执よび慢性気道感染症急性増悪例を対 象とした，急性肺炎は一次性肺炎と二次性肺炎の 2 群に分けた。一次性肺炎之は基礎疾患のない患 者, あるいは呼吸器感染症とは直接結びつかない 基礎疾患のある患者の肺炎である。二次性肺炎と は肺癌, 心不全, 気管支喘息, 肺気腫, 慢性気管 支炎, 気管支拡張症, 肺線維症, 陳旧性肺結核症 など肺自体に基礎疾患のみられる患者の肺炎であ る. 慢性気道感染症急性増覀は慢性気管支炎, 肺 気腫, びまん性汎細気管支炎, 気管支抎張症など の慢性気道感染症で急性増悪を認めた症例であ
る。ただし肺炎例は二次性肺炎とし，あくまでも 気道感染のみを対象とした。 また先行して他の抗 生剂投与がされている場合はそれが無効である症 例のみを対象とした。

\section{3. 対象病原菌}

グラム陽性球菌，グラム陰性桿菌，嫌気性菌な ぞが原因菌となった呼吸器感染症を対象とした。 また，喀痰培養にて原因菌は決定できなかったが 細菌性の呼吸器感染と考学られる症例も対象とし た.しかし P. aeruginosaは対象外とした。

4. 除外規定

1）極めて重篤な症例

2）重篤な心，肝，腎機能障害のある症例

3）P. aeruginosa など原因菌が CFX に耐性で あることが明らかな症例

4) penicillin系, cephem 系抗生剂に対してア レルギーの既往のある症例

5）Cefoxitin 皮内反応試験が陽性の症例

6）前投与抗生剂により症状の改善しつつある 症例

7）妊婦または授乳中の症例

8）その他主治医が不適当と判断した症例

II 試験薬剤およびその溶解方法

1 バイアル中に $1 g$ または $2 g$ の CFX を含有 するマーキシン注射用を，注射用蒸留水，5\%ブ ドウ糖液, 生理食塩液のいずれかを用いて CFX $1 \mathrm{~g}$ に対して $10 \mathrm{ml}$ で溶解した。溶解後はなるべ く速やかに投与した。なお，点滴静注の場合には さらに $5 \%$ ブドウ糖注射液 $100 \sim 500 \mathrm{ml}$ に加えて 用いることとした。

III. 用法・用量 


\section{1) 投与量}

1 日量 $4 g$ を 2 回に分割投与した。ただし症状 扣よび原因菌の感受性から主治医が適宜判断し, 投与量の増減を行らことを可とした。

2）投与方法

静脈内注射をたは点滴静注とし, 前者は $3 \sim 5$ 分，後者40〜120分をかけて投与した。

3）投与期間

原則として14日間としたが，主治医の判断によ る期間の延長は可とした。14日間以前に投薬を中 止する場合は以下の規定に従った。

a）症状が改善・治癒し，投薬の必要性がなく なった場合。

b) 投与中，CFX 耐性菌による感染であること が判明した場合.

c）感染症状が悪化し，継続投与が因難と認め られた場合

d）アレルギー・過敏症が出現した場合.

$e$ ) 副作用, 臨床検査値の異常が発現し, 本剂投 与の続行が不適当と認められた場合.

$f$ ）基礎疾患の悪化，その他の理由で試験の続 行が不適当と考兄られる場合, な挆無効の判定は 投与開始後, 最低72時間を経過した後に行うもの とした。

IV. 併用薬剂・処置

1) 原則として他の抗菌製剂(抗結核剤の取り扱 いは, SM, KM, RFP, EVM, LVM, CPRH, VM 以外はこの限りでない）の併用は禁止した。

2）原則として本研究の薬効評価に影響を与え る薬剤の併用を禁止した。やむをえず使用した場 合にはその薬剤名, 用法, 用量を調査表に必ず記 載することとした。

3）補液,強心剂投与など一般的処置ならびに基 礎疾患, 合併症に対する処置および薬剤は必ず記 載することとした。

\section{V. 臨木症状の観察}

次に述べる観察項目を原則として毎日記録し た。すなわち，体温：実測値(最高), 脈拍数：実 測值 (/分), 呼吸数：実測值 (/分), 喀疢：1 日 量 $(m l$ : 少量ならば個数) で記載し量の測定が出 来ない場合は+ (多い), + (少ない) - (正常) の
3 段階で評価. 性状：膿性（P), 粘膿性 (PM), 粘性 (M)の 3 段階. 色調: 黄色 (Y), 白色 (W), 透明（T）の 3 種類。胸部 5 音:,,++ , の 3 段 階。咳嗽：一(睡眠が障害される程度), 十, 一の 3 段階, 胸痛:,,$++ 一$ - 3 段階. 呼吸困難: ,,$++ 一$, 3 段階. 脱水症状:,+- , 2 段階. 于 アノーゼ : +, 一の 2 段階

\section{VI. 臨床検查}

以下検査項目を $\mathrm{CFX}$ 投与前後に実施記録し， 可能な限り 7 日目にも検査することとした。すな わち, 胸部レ線, 血液検查 (赤血球数, へモグロ ビン量, ヘマトクリット值, 白血球数, 白血球像, 血小板数), 血液生化学検查 (血清総蛋白, BUN, creatinine, GOT, GPT, Al-p) 尿検査（蛋白, 糖) その他, 血沈, $\mathrm{CRP}$, 寒冷凝集反応, マイコプラ ズマ抗体, クームステスト(直接または間接), $\mathrm{HB}$ 抗原掞よび抗体価などの検査を行った。

VII. 細菌学的検査

$\mathrm{CFX}$ 投与前後に菌検索を行い, 検出菌の同定な らびに薬剤感受性試験を実施記録することとし た。

VIII. 効果判定

\section{1. 主治医判定}

1）臨床効果判定

臨床所見, 臨床検査值の改善をもとに主治医が 投与終了日に, 著効, 有効, やや有効, 無効の 4 段階に判定し, 判定できない症例は判定不能とし た。

\section{2) 細菌学的効果判定}

原因菌が検出できた症例では，その菌の消長か ら消失, 減少, 不変, 菌交代, 判定不能のいずれ かに判定をすることとした。

\section{2. 委員会判定}

効果判定に客観性をもたせるために 4 施設 5 名 の医師からなる小委員会（構成委員 : 山本俊幸, 北浦三郎，永坂博彦，鈴木幹三，加藤政仁）を設 立し, 主治医の判定も参考にして全症例を対象と し採用しらるか否かの検討を行った，採用症例に ついては初診時症状㧍よび検査所見より, 重症, 中等症, 軽症の 3 段階に分け, 効果判定は, 胸部 レ線像の改善度, 体温, チアノーゼ, 呼吸困難, 
喀痰量, 胸部ラ音, 白血球数, CRP などの改善の 程度と速さにより，また，宿主側の要因も参考に して, 下記の判定基準により効果判定を行った。

著効：薬剤投与後 7 日以内にすべての自・他覚症 状の消失ないし著しい改善がみられたもの.

有効：7 日以内に明かな改善がみられたもの. やや有効：7 日以内に軽度の改善がみられたも の.

無効：7 日以内に改善のみやれなかったもの.な お，判定が分かれる場合は 5 人の委員の協議によ り決定することとした。

IX 副作用

主治医の観察扣よび患者の報告により本剂と関 連があると考えられた副作用は, その症状, 程度, 出現の時期, 投薬継続の可否, 処置, 経過などを できる限り詳細に記載することとした。また。臨 床検査値異常が出現した場合には本剂との関係, それに対する処置，その後の経過などをできる限 り追跡調査し, CFX 投与に併ら副作用の最終判定 定は小委員会に打いて行らこととした。

$\mathrm{X}$ 有用性判定

臨床効果, 細菌学的効果, 副作用招よび臨床検 査値異常の有無をもとに小委員会に拈いて，極め て有用，かなり有用，やや有用，有用と思われな い.の 4 段階で有用性を判定することとした。

\section{試験成績}

\section{1. 対象例}

$\mathrm{CFX}$ 投与総症例数は66例である. 各症例ごとに 小委員会で検討し，そのうち55例を効果判定対象
とした（Table 2, Table 3). 除外例とした11例を Table 4 に示す。すなお, Case 56, Case 57 は 重篤な基礎疾患のため，それぞれ投与 5 日目，投 与 1 日目に死亡した. Case 58, Case 59 は前投薬 の piperacillin, talampicillin にてかなりの改善 がみられていた. Case 60 は上気道感染のみであ り, Case 61 は感染症状が不明確であった. Case 62は経過中に喀血をきたし主治医が途中で投与を 中止した症例である。

Case 63, Case 64 は原因菌が $P$. aeruginosa で あった. Case 65 は steroidを併用していた. Case 66 は肺炎として治療していたが，後に結核菌培養 が陽性と判明した。 以上のような理由でこれらの 症例は除外例とした。

副作用については，重篤な基礎疾患にて死亡し た Case 56, Cape 57, 効果判定除外例のため投与 後の検査が不備であった Case 64 を除いた63症例 を検討の対象とした（Table 5).

2. 効果判定対象患者の性別々年齢分布

男性 38 人, 女性 17 人と男性が多く, 年齢は $22 \sim 93$ 歳に分布し，60歳以上が全体の $67 \%$ 占めた (Table 6).

\section{3. 病名と重症度}

基礎疾患のない患者，扣よび高血圧症，胃潰瘍， 脳血管障害, 貧血, 肝胆道疾患, コントロール良 好の糖尿病など直接呼吸器感染と結びつかない基 礎疾患のある患者での肺炎，すなわち一次性肺炎 は26症例である（Case 1 Case 26），肺癌，心不 全, 気管支喘息, 肺気腫, 慢性気管支炎, 気管支

Table 2 Patient distribution

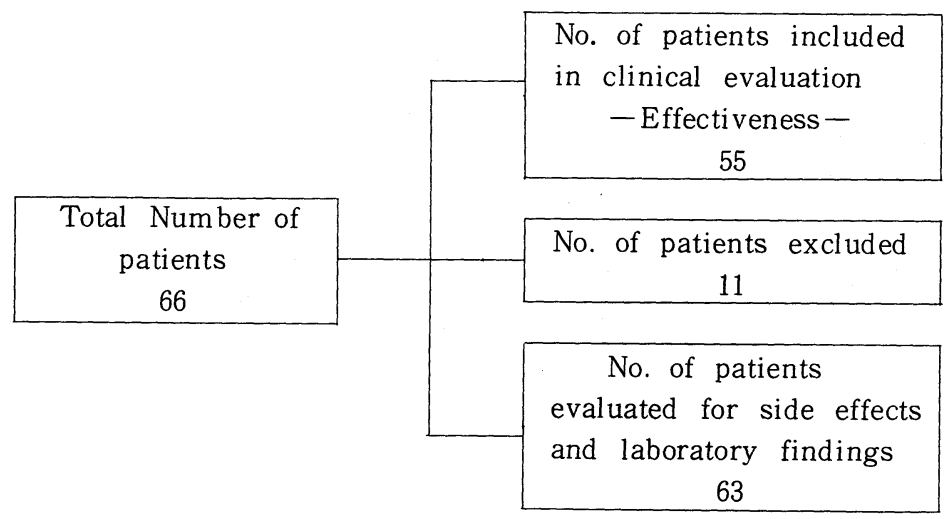




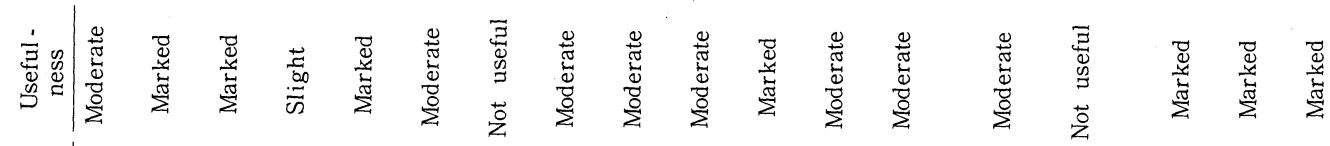

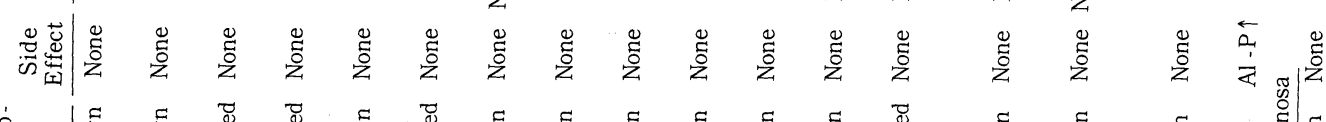

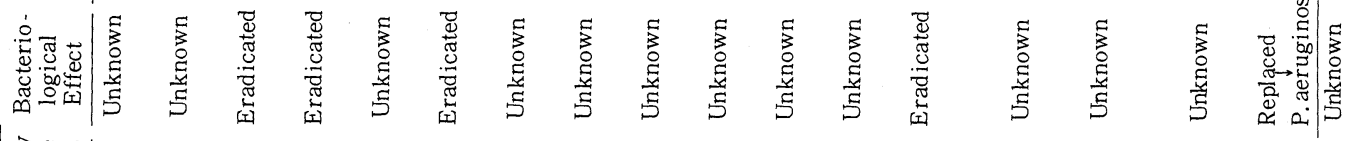

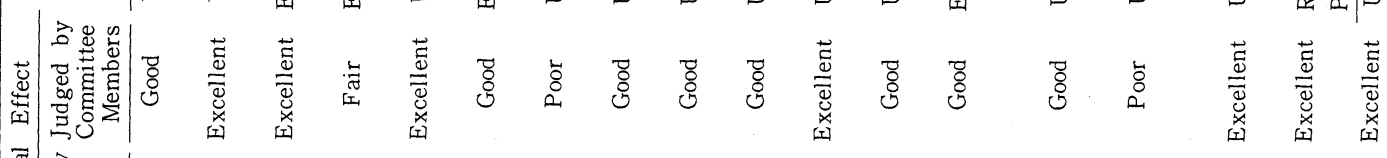

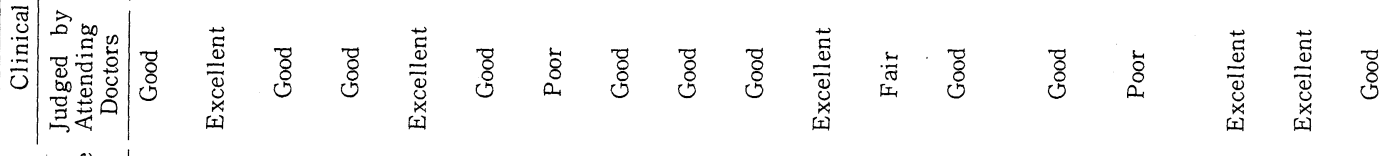
焉

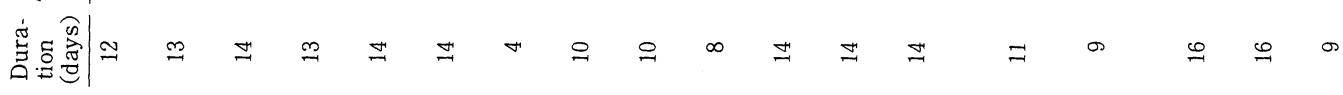

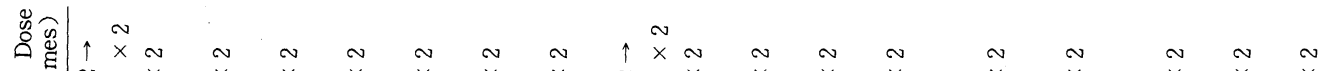

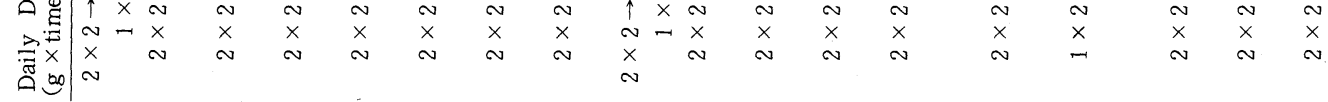

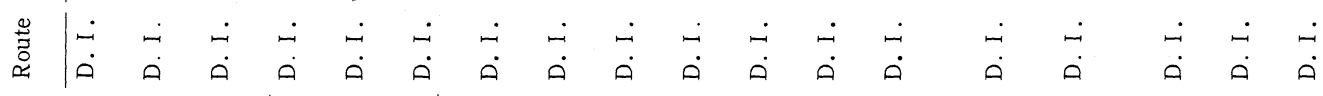

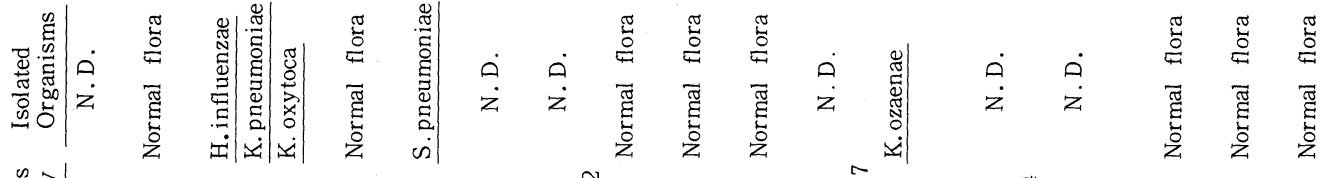

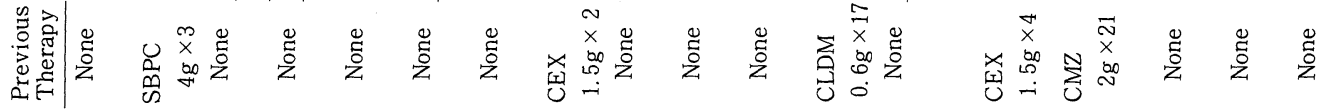

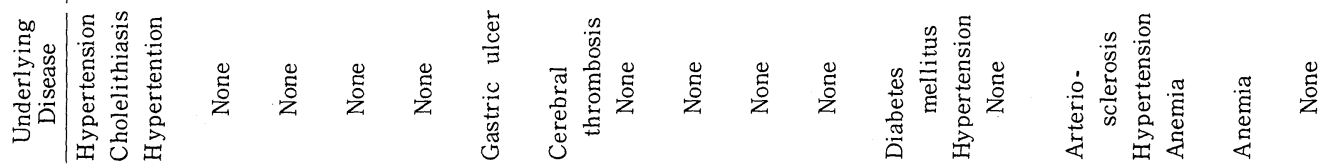

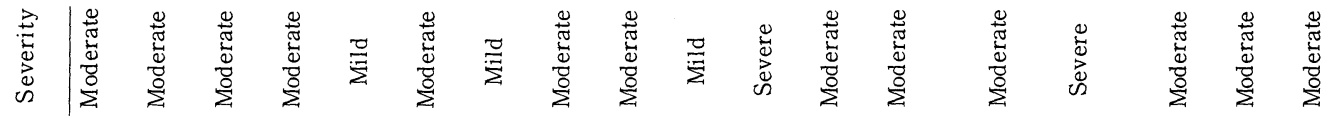

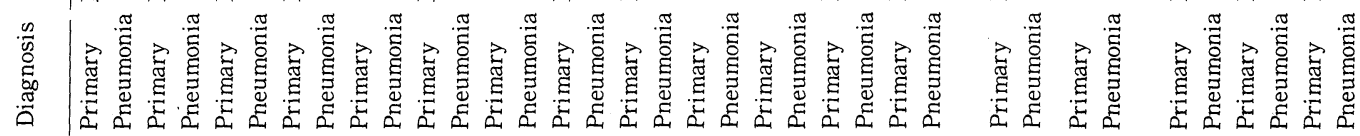

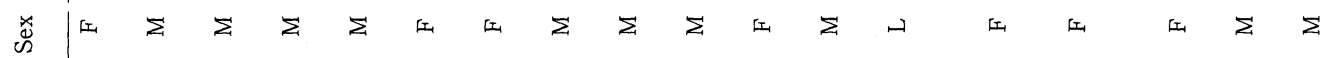

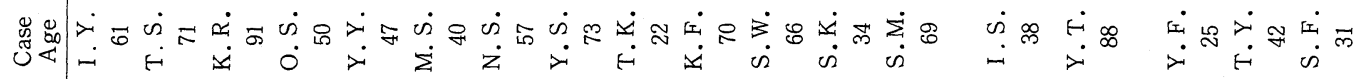

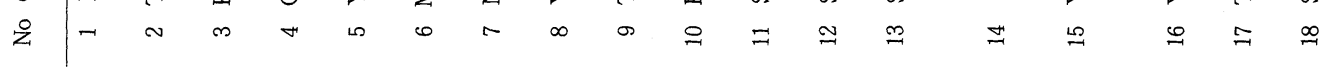




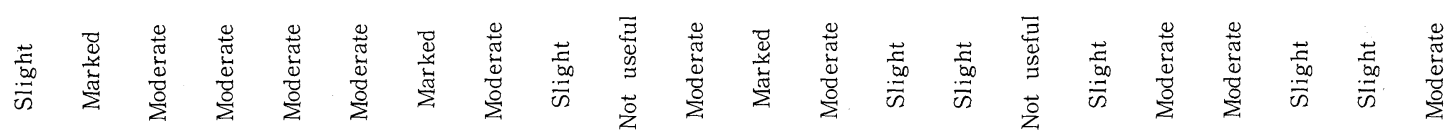
苛 茫

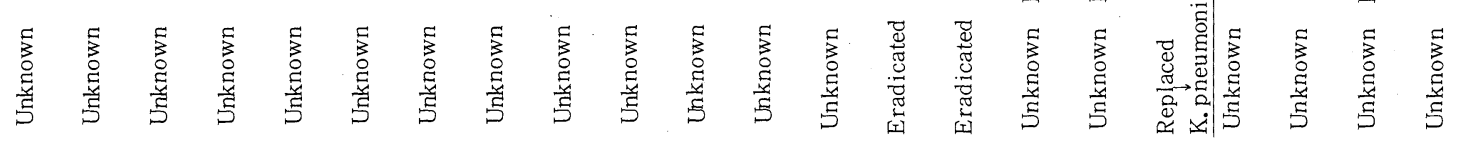

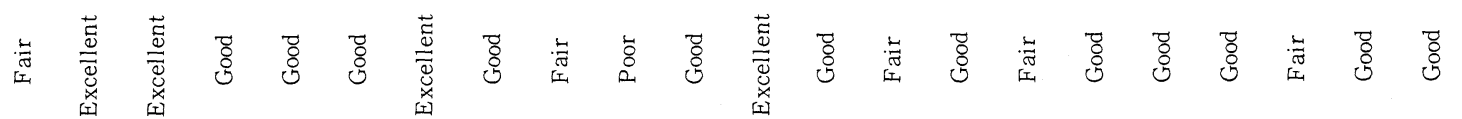

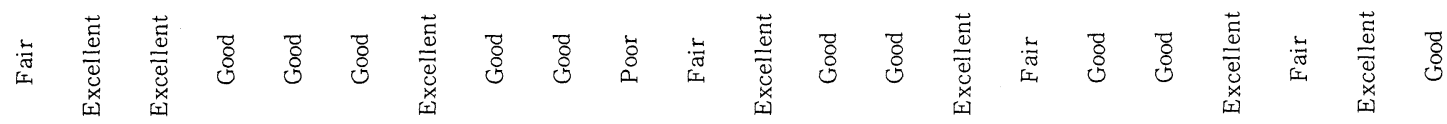
芦

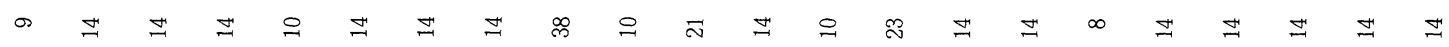

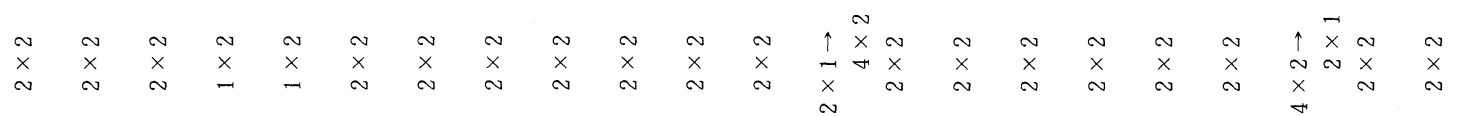

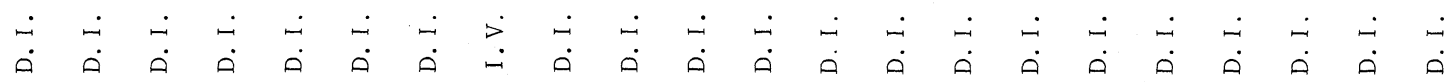

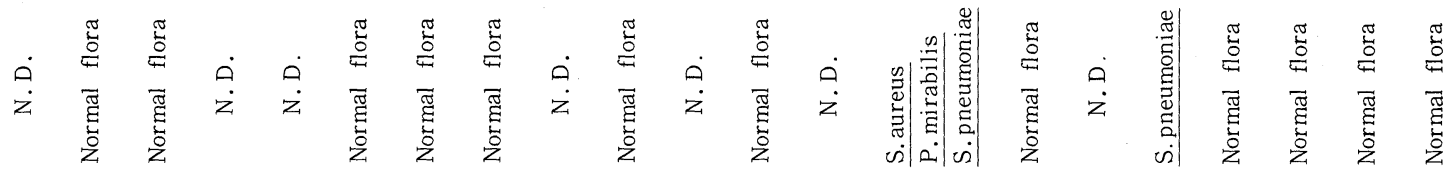
党 芯

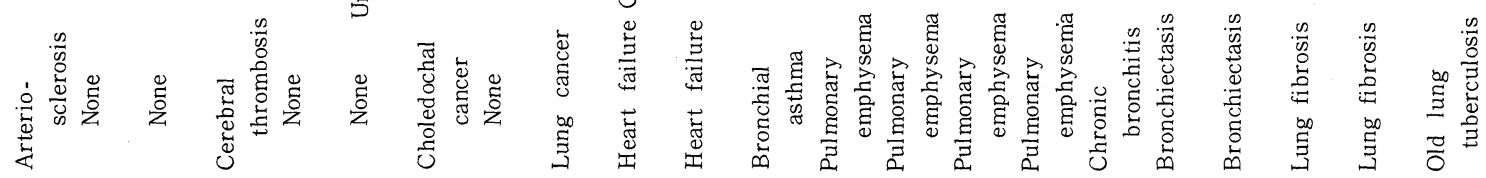

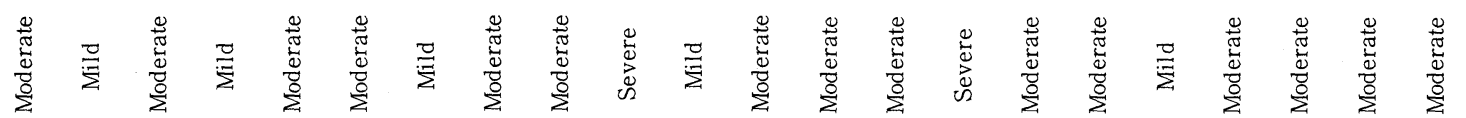

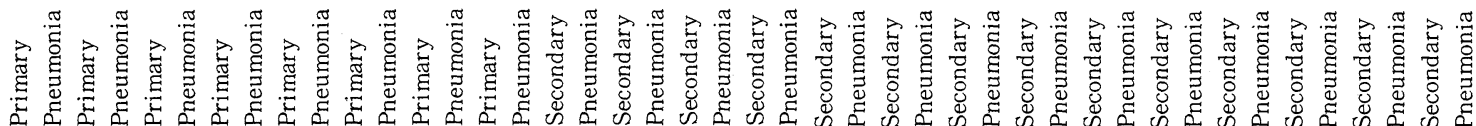

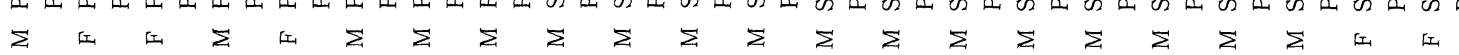

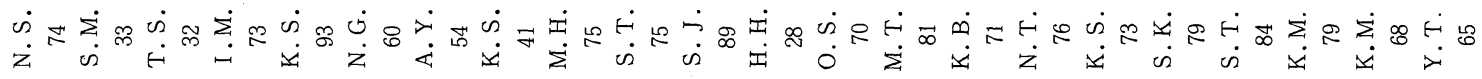

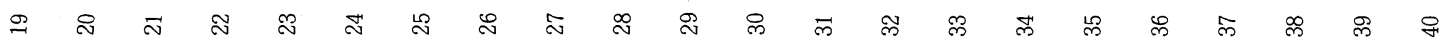




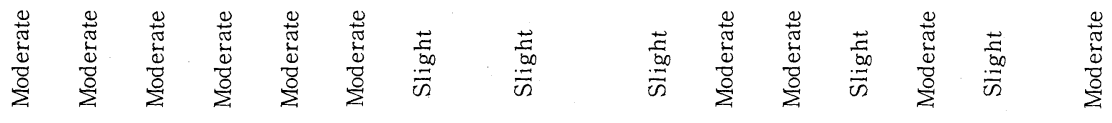

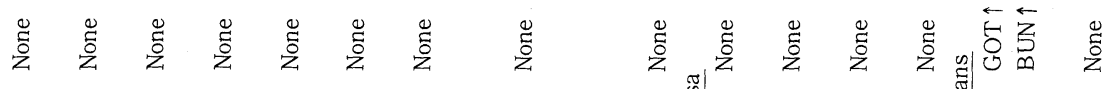

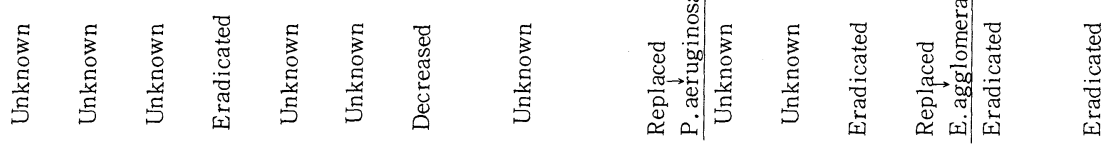

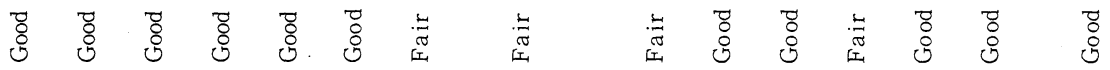

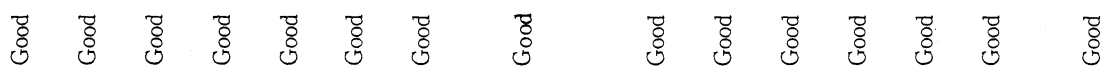
郘

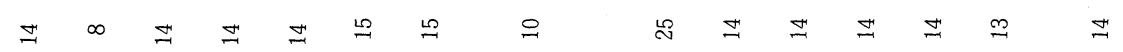

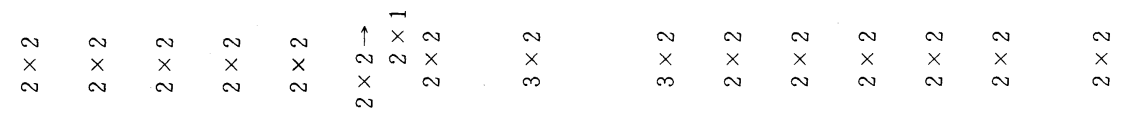

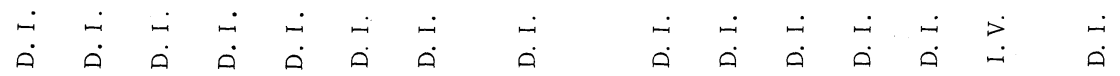

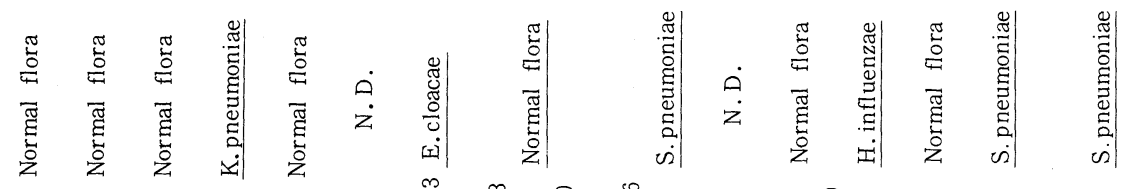

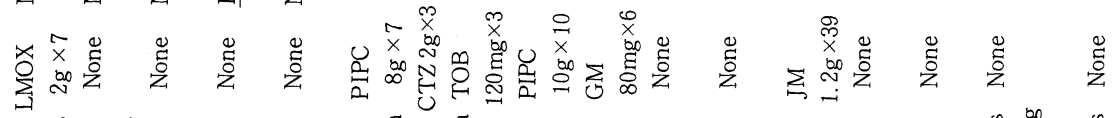

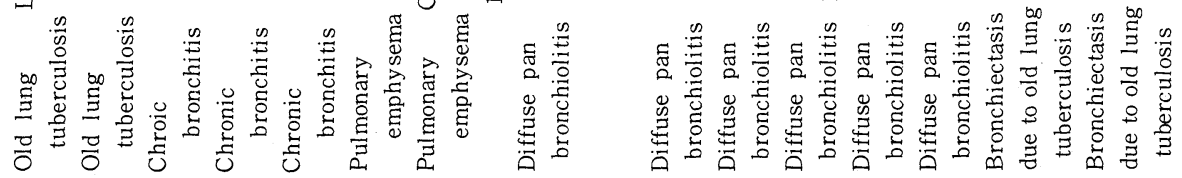

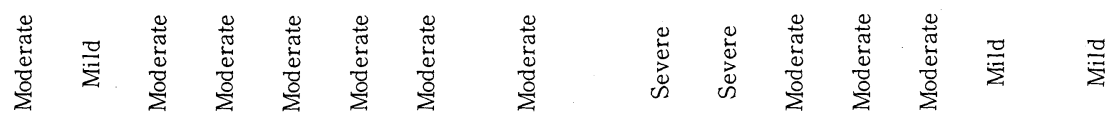

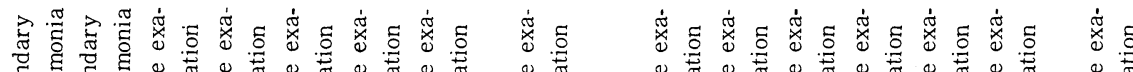

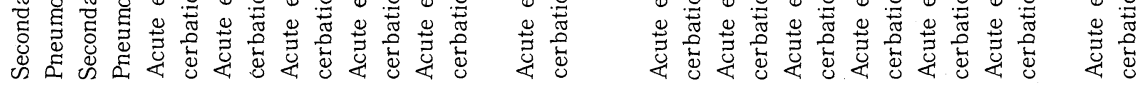

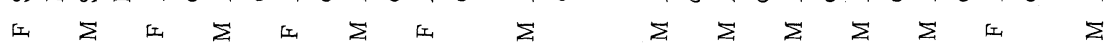

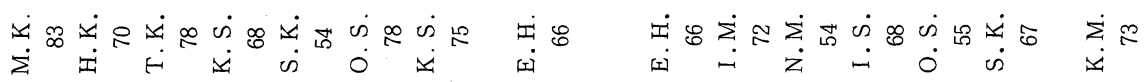

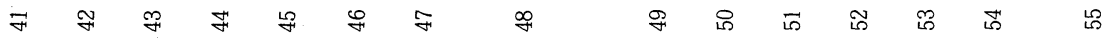




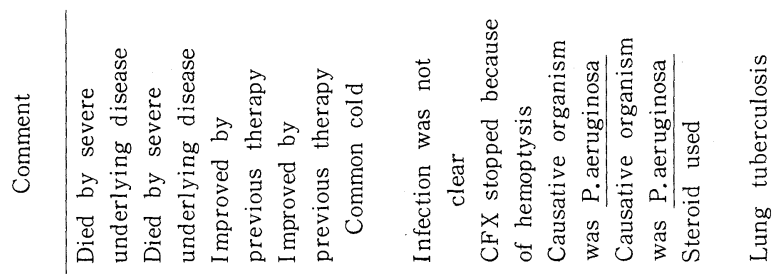

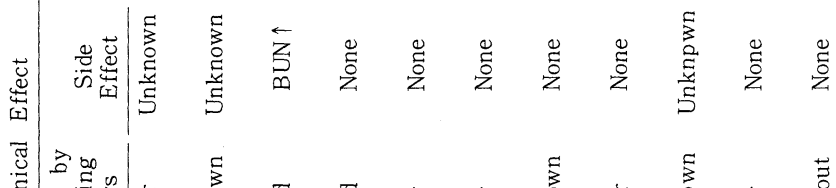

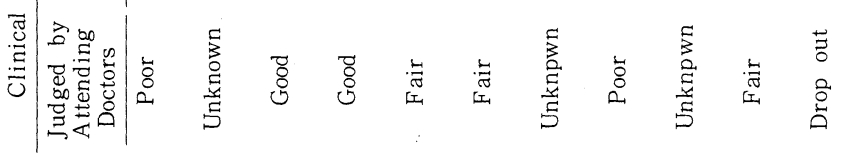

䒰

葛

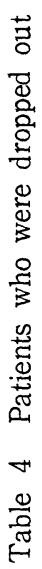

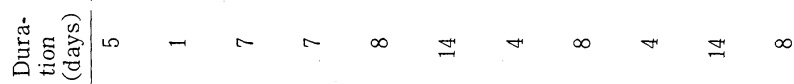

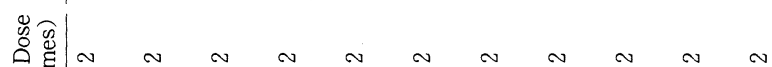

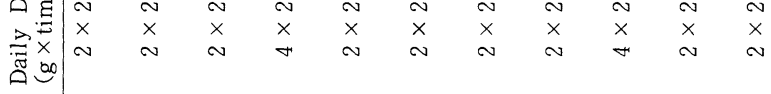

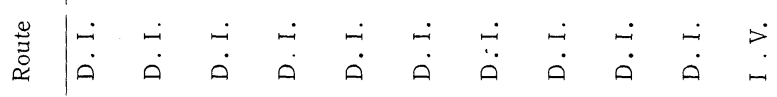

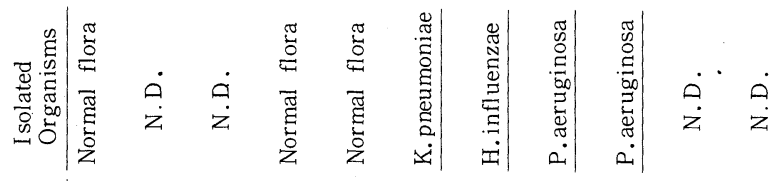

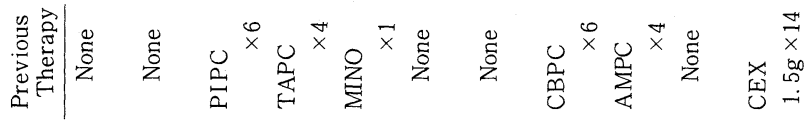

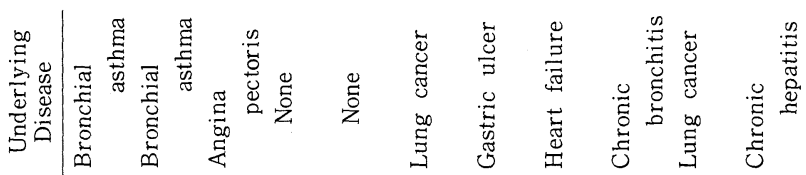

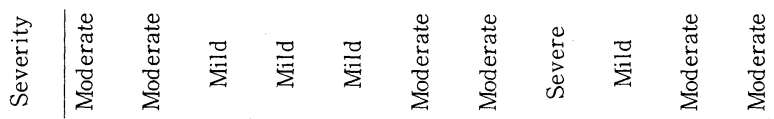

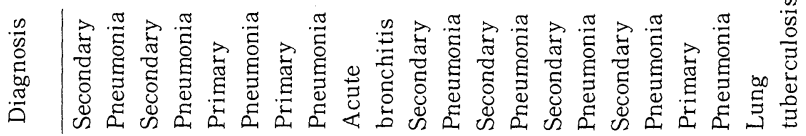

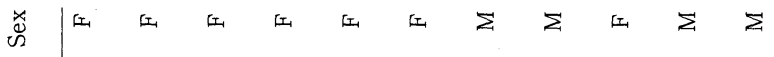

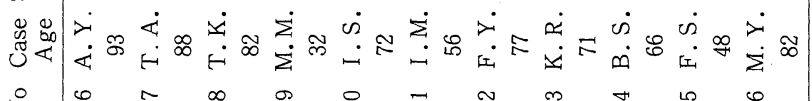

吕 


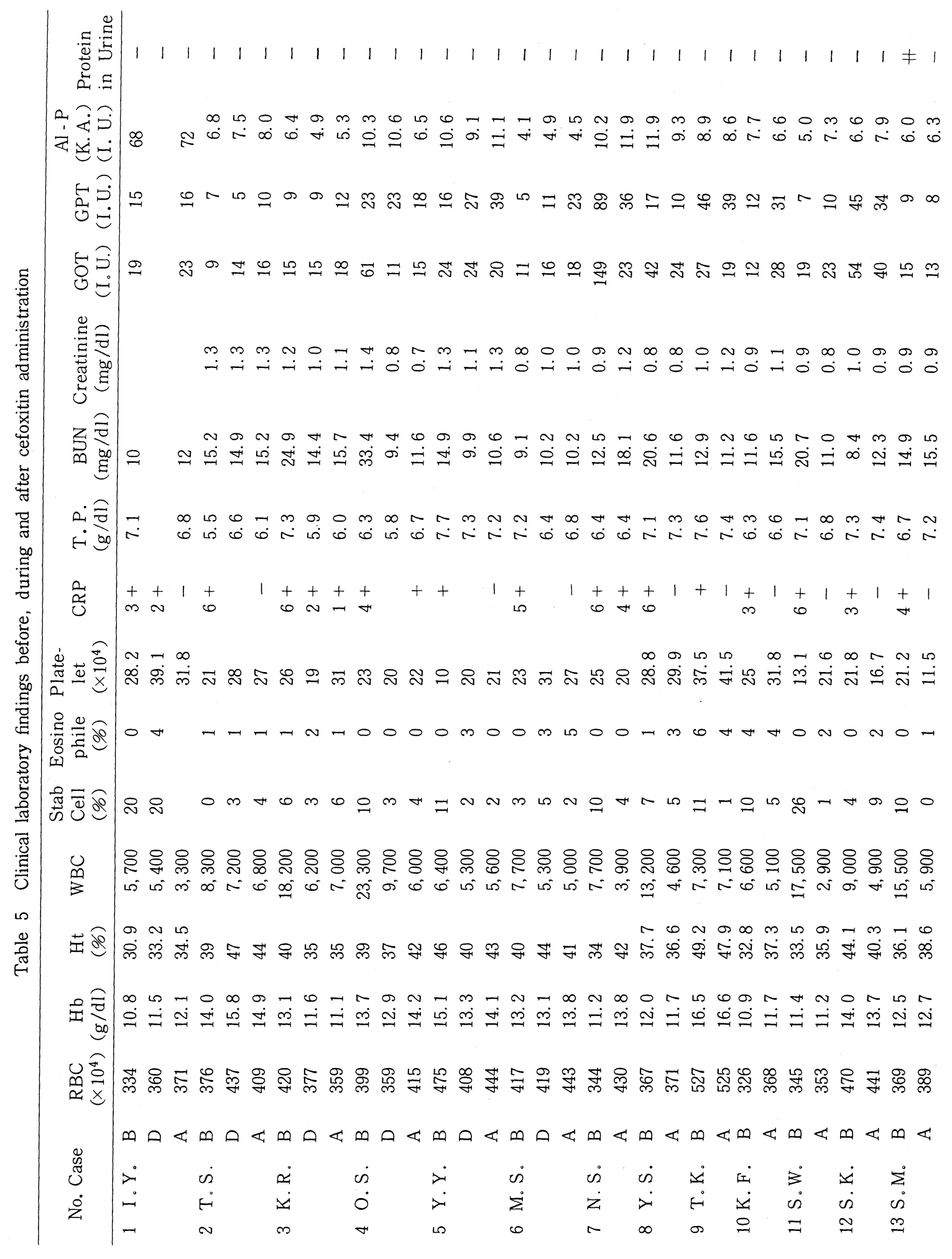




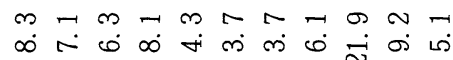

뇽요

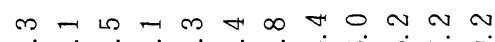

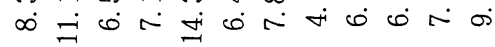

$\sim \infty \quad \infty \rightarrow$ m

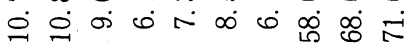

m

$\infty \sigma \sigma \infty \sim \sim \sim 0$ เ

$\dot{0} \dot{0} \dot{0} \dot{0} \dot{0} \dot{0} \dot{0} \dot{0}-\dot{H}$

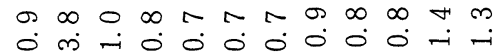

$\infty$

$\stackrel{\sim}{\sim}$ $\forall \forall \sigma 6 \omega \infty \pi$ $\dot{\infty} \cong$ ஸे

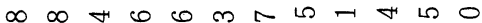

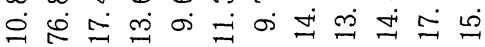

L 0 H

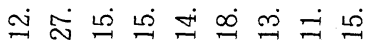

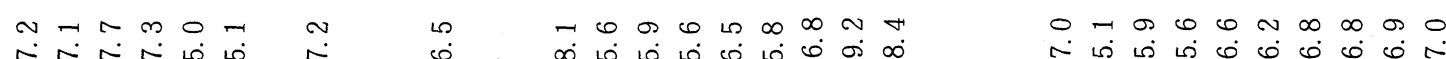

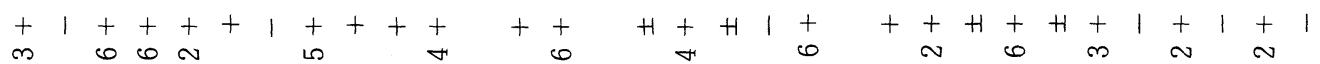

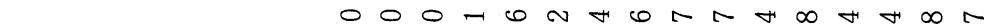
尔 on 0 h m n

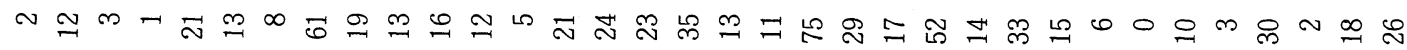

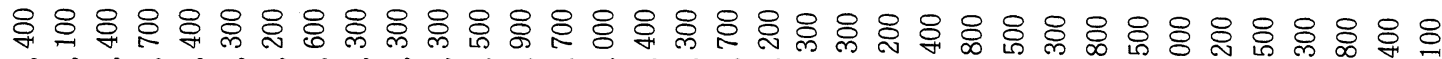
IN N $m m \infty N \quad-00$ -

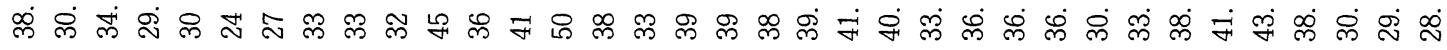

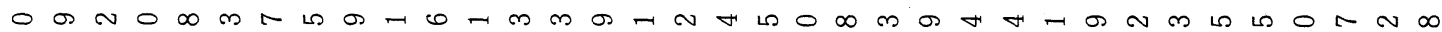

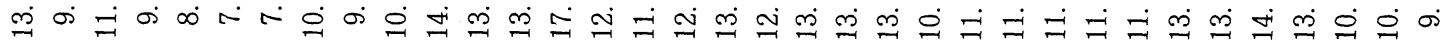

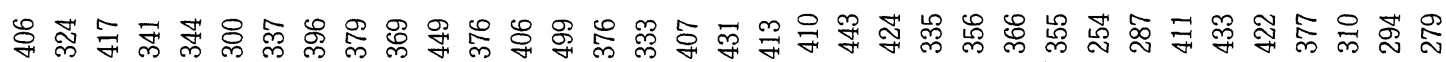

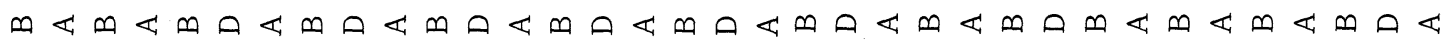

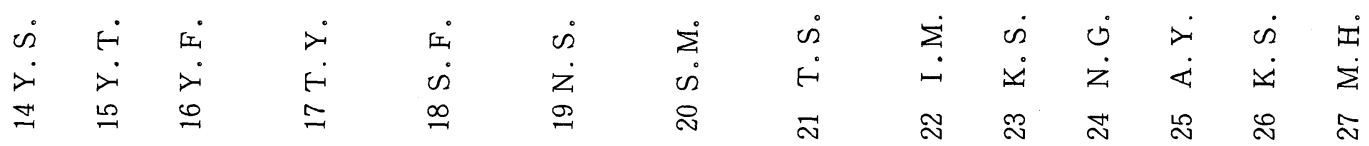


$\neq+111111111111+1+1$

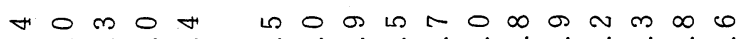
O 0 O $\sim N \omega$ N म के

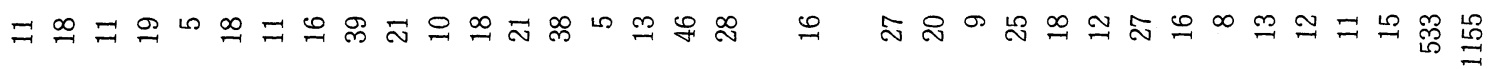
స o)

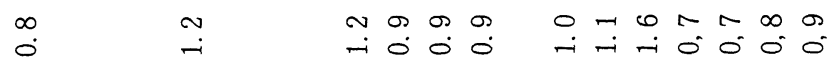
0 o 0 L 더둬

0000 H

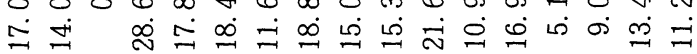

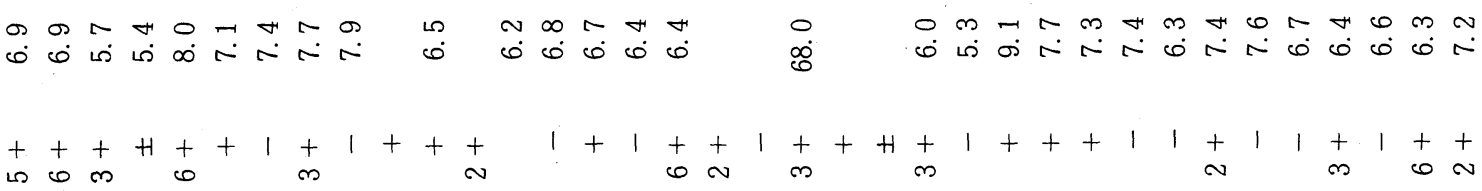
D 0 L 0 H m

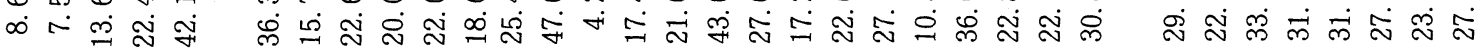

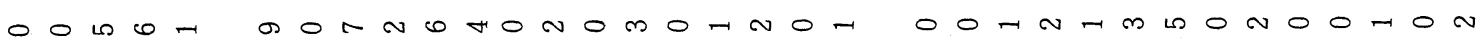
- の

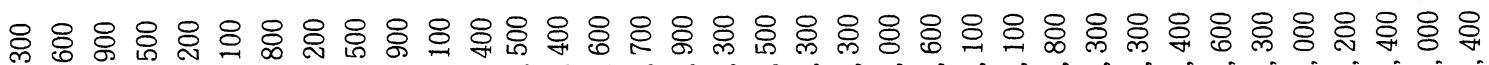

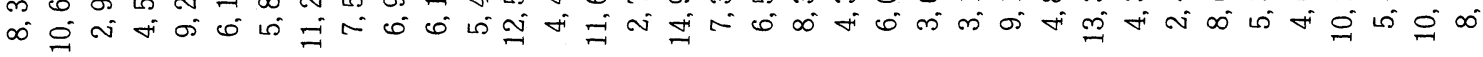

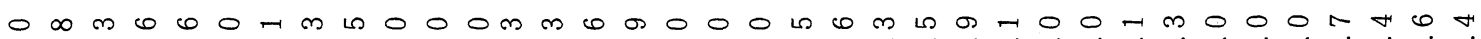
மீं க்

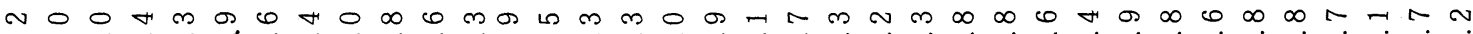

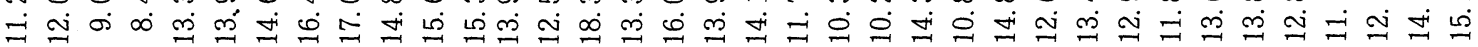

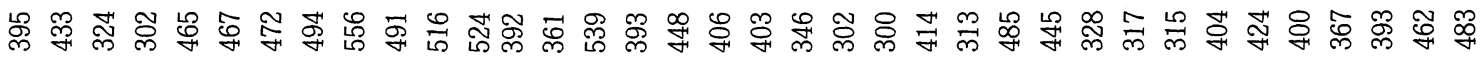

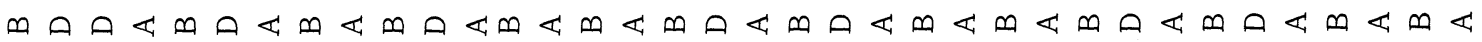

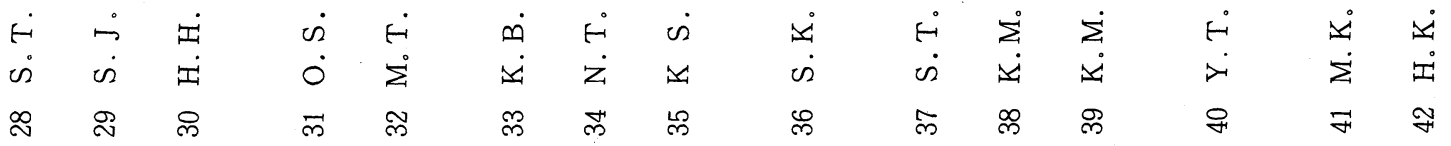




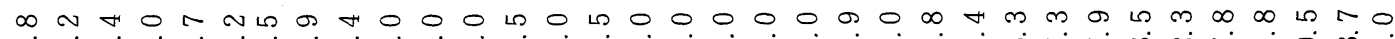

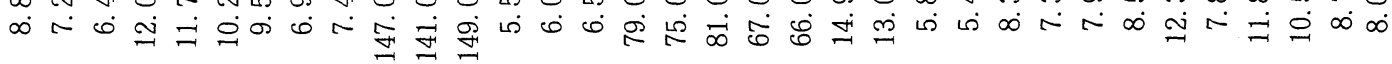
그음 兆프

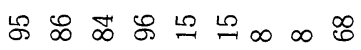

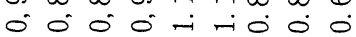

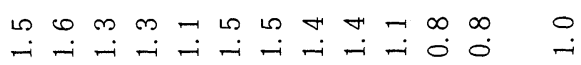

$\stackrel{+}{\circ}$

a n H H ப்

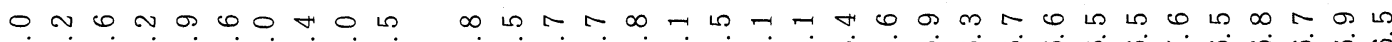
ம

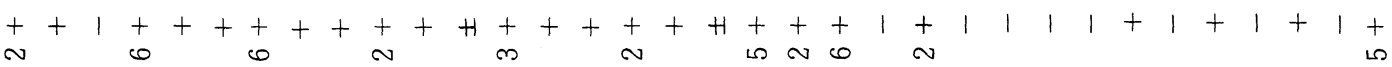

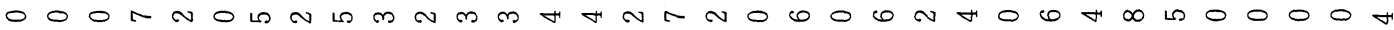
宛

ro

虫

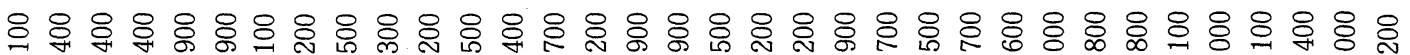

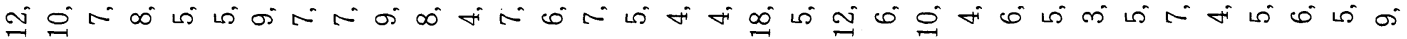

o 0 o 0 m 0 m

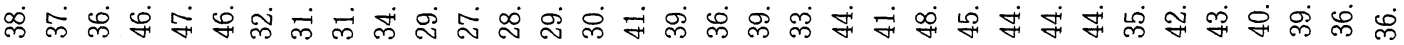

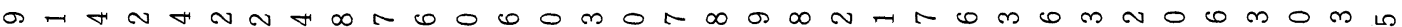

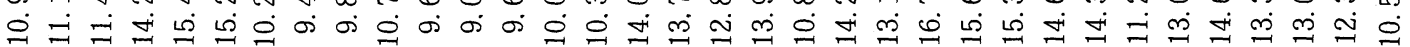

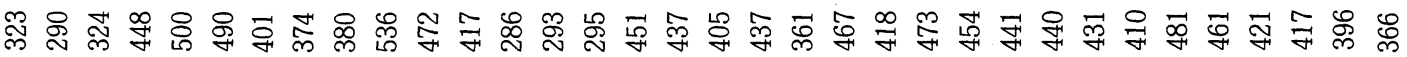

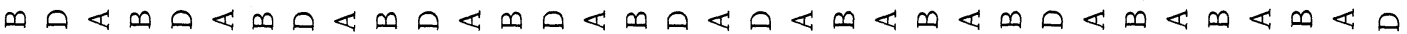

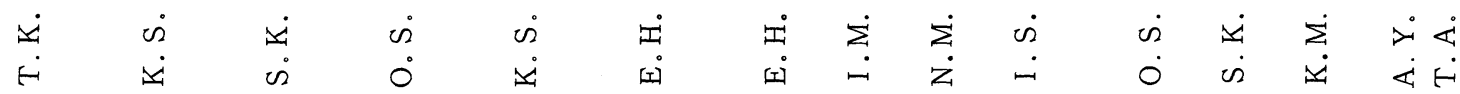

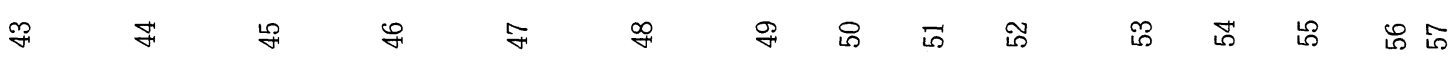




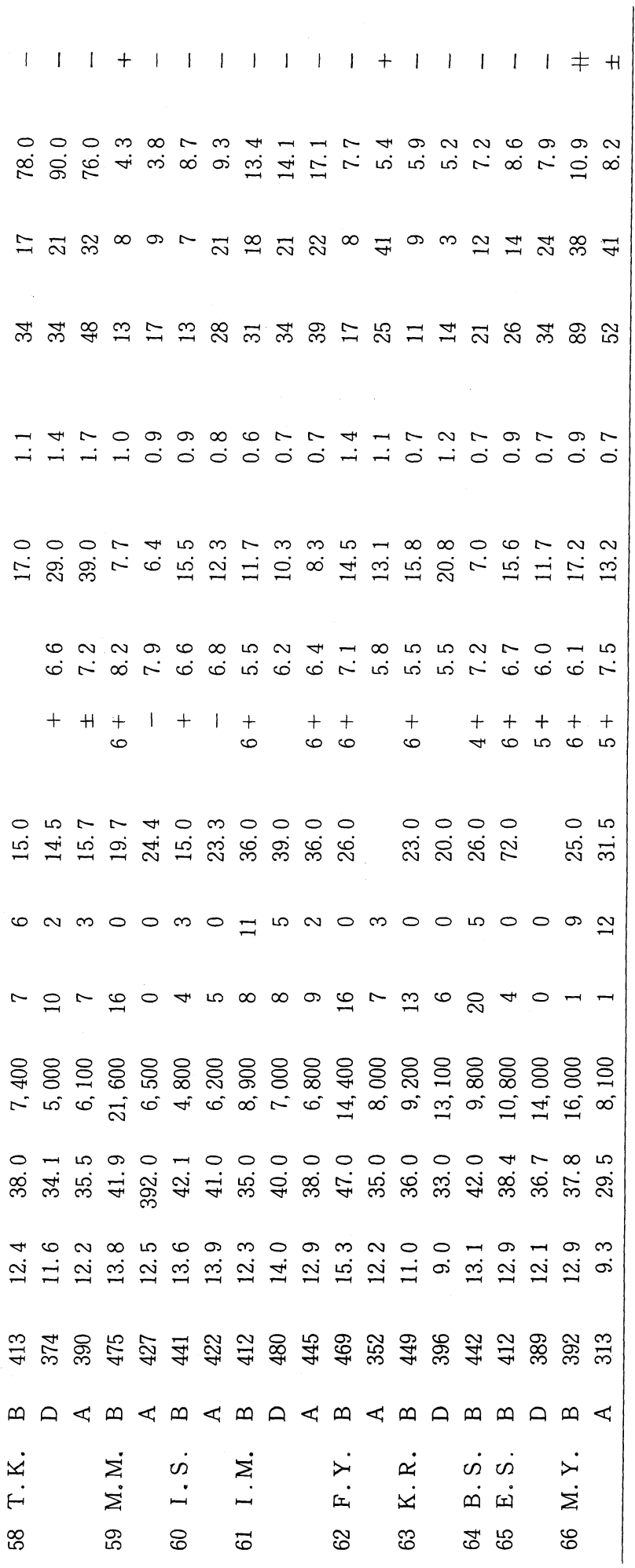


Table 6 Age and sex distribution

\begin{tabular}{lcccccccc}
\hline Sex Age & $20-29$ & $30-39$ & $40-49$ & $50-59$ & $60-69$ & $70-79$ & $80-$ & Total \\
\hline Male & 2 & 2 & 3 & 4 & 6 & 17 & 4 & 38 \\
Female & 1 & 3 & 1 & 2 & 5 & 2 & 3 & 17 \\
\hline Total & 3 & 5 & 4 & 6 & 11 & 19 & 7 & 55 \\
\hline
\end{tabular}

Table 7 Diagnosis and severity in patients with cefoxitin

\begin{tabular}{lcccc}
\hline \multirow{2}{*}{ Diagnosis } & \multicolumn{3}{c}{ Severity } & \multirow{2}{*}{ Total } \\
\cline { 2 - 4 } & Mild & Moderate & Severe & \\
\hline Primary Pneumonia & 6 & 18 & 2 & 26 \\
$\begin{array}{l}\text { Secondary Pneumonia } \\
\text { Acute Exacerbation of }\end{array}$ & 3 & 11 & 2 & 16 \\
$\begin{array}{l}\text { Chronic Bronchial Tract } \\
\text { Infection }\end{array}$ & 2 & 9 & 2 & 13 \\
\hline \multicolumn{1}{c}{ Total } & 11 & 38 & 6 & 55 \\
\hline
\end{tabular}

抎張症, 肺線維症, 陳旧性肺結核症など肺自体に 基礎疾患のみられた患者での肺炎，すなわち二次 性肺炎は16症例である（Case 27〜Case 42）.

慢性気管支炎, 肺気腫, びをん性沉細気管支炎, 気管支拡張症などの慢性気道感染症の急性増悪は 13症例である (Case 43〜Case 55). 個々の重症度 は Table 7 に示すごとくで, 全体で, 軽症11例, 中等症38例, 重症 6 例であった.

4. 1 日投与量および投与期間

CFXの 1 日投与量は $2 \mathrm{~g} \sim 8 \mathrm{~g}$ に分布し, $4 \mathrm{~g}$ が 48 症例 $(87.2 \%$ ) ともっとも多かった。な拈，途中 で投与量を変更した症例が 5 例 $(4 \mathrm{~g} \rightarrow 2 \mathrm{~g}$ : Case $1,9,46 ; 2 \mathrm{~g} \rightarrow 8 \mathrm{~g}$ : Case $31 ; 8 \mathrm{~g} \rightarrow 2 \mathrm{~g}:$ Case 38) あるが，効果発現に関連したと考兄られる投与量 の多い方を選択した（Table 8).

1 日 2 回, 朝夕に分割投与し, 投与期間は $4 \sim 38$ 日, 平均13.7日で大部分は $8 \sim 14$ 日間投与で あった (Table 9).

総投与量は $16 \sim 152 \mathrm{~g}$, 平均 $53.0 \mathrm{~g}$ であり大部分 は41〜60g 投与であった（Table 10）。

\section{5. 原因菌}

$\mathrm{CFX}$ 投与前に喀痰検査を施行し, 原因菌検索を 行った症例は40例である。そのうち13例で原因菌 を検出することができた。すなわち $S$. pneumoniae 6 例 (Case 6, 33, 36, 49, 54, 55), $K$. pneumoniae 1 例(Case 44), $K$. oxytoca 1 例
Table 8 Daily dose of cefoxitin

\begin{tabular}{|c|c|c|}
\hline Daily & Dose $(g)$ & No. of Patients \\
\hline & 2 & 3 \\
\hline & 4 & 48 \\
\hline & 6 & 2 \\
\hline & 8 & 2 \\
\hline & Total & 55 \\
\hline
\end{tabular}

Table 9 Duration of cefoxitin administration

\begin{tabular}{cc}
\hline Duration (Days) & No. of Patients \\
\hline-7 & 1 \\
$8-14$ & 46 \\
$5-$ & 8 \\
\hline Total & 55 \\
\hline & Range $: 4-38$ Days \\
& Average $: 13.7$ Days
\end{tabular}

Table 10 Total dose of cefoxitin

\begin{tabular}{|c|c|c|}
\hline Total Dose $(\mathrm{g})$ & No. of & Patients \\
\hline-20 & & 3 \\
\hline $21-40$ & & 9 \\
\hline $41-60$ & & 37 \\
\hline $61-$ & & 6 \\
\hline \multirow[t]{2}{*}{ Total } & & 55 \\
\hline & $\begin{array}{l}\text { Range } \\
\text { Average }\end{array}$ & $\begin{array}{r}16-152 \mathrm{~g} \\
53.0 \mathrm{~g}\end{array}$ \\
\hline
\end{tabular}


(Case 4), K. ozaenae 1 例(Case 13), E. cloacae 1 例 (Case 47), H. influenzae (Case 52), $H$. influenzae $+K$. pneumoniae 1 例 (Case 3), S. aureus + P. mirabilis 1 例 (Case 32) の計13例で ある。

\section{6. 前投薬}

$\mathrm{CFX}$ 投与前に他の抗生剂が投与され，それが無 効であった症例は11例である。その疾患の内訳は 一次性肺炎 5 例, 二次性肺炎 2 例, 慢性気道感染 症急性増悪 4 例であった。前投与抗生剂は josamycin (Case 51), clindamycin (Case 12), sulbenicillin (Case 2), piperacillin (Case 46), cephalexin (Case 8, 14), cefatrizine (Case 28), cefmetazole (Case 15), latamoxef (Case 41), ceftezole + tobramycin (Case 47), piperacillin+ gentamicin (Case 48) であり, 経口投与 5 例，併 用を含めて注射が 6 例であった。

7. 臨床効果招よび細菌学的効果

1）呼吸器感染症の種類による臨床効果

一次性肺炎では26症例中著効10例，有効12例， やや有効 2 例，無効 2 例で有効率は $84.6 \%$ であっ た。二次性肺炎では，16症例中著効 1 例，有効 10 例，やや有効 4 例，無効 1 例で有効率は $68.8 \%$ で
あった。慢性気道感染症急性増悪では13症例中有 効 9 例, やや有効 4 例で有効率は69.2\%であった。 一次性肺炎に比し, 二次性肺炎, 慢性気道感染症 急性増悪例の有効率は低值であった。全体では著 効 11 例，有効 31 例，やや有効 10 例，無効 3 例であ り，有効率は76.4\%であった（Table 11）。

2) 重症度別臨床効果

一次性肺炎, 二次性肺炎, 慢性気道感染症急性 増悪例すべてについて重症度から臨床効果を検討 すると, 軽度 11 症例では著効 3 例, 有効 7 例, 無 効 1 例であり，有効率は $90.9 \%$ であった。中等症 38 症例では著効 7 例，有効 22 例，やや有効 9 例で あり，有効率は $76.3 \%$ であった。重症 6 症例では， 著効 1 例, 有効 2 例, やや有効 1 例, 無効 2 例で 有効率は50.0\%であった。重症度が強くなるに 従って有効率の低下がみられた（Table 12）。

3）総投与量と臨床効果

全症例を総投与量より分類して臨床効果を検討 すると，総投与量 $20 \mathrm{~g}$ 以下, $21 \mathrm{~g} \sim 40 \mathrm{~g}, 41 \mathrm{~g} \sim 60 \mathrm{~g}$, $61 \mathrm{~g}$ 以上の 4 群での有効率はそれぞれ $33.3 \%$, $77.8 \%, 86.5 \%, 33.3 \%$ あった. 投与量の増加 により有効率の上昇がみられた。しかし $61 \mathrm{~g}$ 以上 の投与では有効率が低下し無効例の増加が認めら

Table 11 Clinical results classified by diagnosis

\begin{tabular}{|c|c|c|c|c|c|}
\hline \multirow{2}{*}{ Diagnosis } & \multicolumn{4}{|c|}{ Evaluation } & \multirow{2}{*}{$\begin{array}{l}\text { Efficacy } \\
\text { Rate }(\%)\end{array}$} \\
\hline & Excellent & Good & Fair & Poor & \\
\hline Primary Pneumonia & 10 & 12 & 2 & 2 & 84.6 \\
\hline Secondary Pneumonia & 1 & 10 & 4 & 1 & 68.8 \\
\hline $\begin{array}{l}\text { Acute Exacerbation of } \\
\text { Chronic Bronchial Tract } \\
\text { Infection }\end{array}$ & & 9 & 4 & & 69.2 \\
\hline Total & 11 & 31 & 10 & 3 & 76.4 \\
\hline
\end{tabular}

Table 12 Clinical results classified by severity of illness

\begin{tabular}{lcccccc}
\hline \multirow{2}{*}{ Severity } & \multicolumn{5}{c}{ No. of Patients } & Efficacy \\
\cline { 2 - 6 } & Total & Excellent & Good & Fair & Poor & Rate $(\%)$ \\
\hline Mild & 11 & 3 & 7 & 0 & 1 & 90.9 \\
Moderate & 38 & 7 & 22 & 9 & 0 & 76.3 \\
Severe & 6 & 1 & 2 & 1 & 2 & 50.0 \\
\hline \multicolumn{1}{c}{ Total } & 55 & 11 & 31 & 10 & 3 & 76.4 \\
\hline
\end{tabular}


れた (Table 13).

4) 年齢別臨床効果

全症例を年齢により 2 群に分け臨床効果を検討 した. 69歳以下の 29 症例では, 著効 9 例, 有効 15 例, やや有効 4 例, 無効 1 例で有効率は $82.8 \%$ で あった，70歳以上の 26 症例では，著効 2 例，有効 16例, やや有効 6 例, 無効 2 例となり有効率は, $69.2 \%$ と前者に比して低率で，高齢者群に有効率 の低下がみられた（Table 14）。

\section{5）原因菌別臨床効果}

13症例中 S. pneumoniae が検出された 6 例で は有効 5 例，やや有効 1 例であった。グラム陰性 桿菌の検出された症例中の有効症例は, $K$. pneumoniae, $K$. ozaenae, $H$. influenzae $+K$. pneumoniae がそれぞれ検出された3 例である.や や有効にとどまった症例は $K$. oxytoca, E. cloacae, H. influenzae, S. aureus $+P$. mirabilis がそれぞれに検出された 4 例である（Table 1

Table 13 Clinical results classified by total dose of CFX

\begin{tabular}{crrrrrr}
\hline Total Dose & \multicolumn{5}{c}{ No. of Patients } & Efficacy \\
\cline { 2 - 6 }$(\mathrm{g})$ & Total & Excellent & Good & Fair & Poor & Rate (\%) \\
\hline-20 & 3 & & 1 & & 2 & 33.3 \\
$21-40$ & 9 & 1 & 6 & 1 & 1 & 77.8 \\
$41-60$ & 37 & 10 & 22 & 5 & & 86.5 \\
$61-$ & 6 & & 2 & 4 & & 33.3 \\
\hline Total & 55 & 11 & 31 & 10 & 3 & 76.4 \\
\hline
\end{tabular}

Table 14 Clinical results classified by AGE

\begin{tabular}{ccccccc}
\hline Age & \multicolumn{5}{c}{ No. of Patients } & Efficacy \\
(years) & Total & Excellent & Good & Fair & Poor & Rate (\%) \\
\hline-69 & 29 & 9 & 15 & 4 & 1 & 82.8 \\
$70-$ & 26 & 2 & 16 & 6 & 2 & 69.2 \\
\hline Total & 55 & 11 & 31 & 10 & 3 & 76.4 \\
\hline
\end{tabular}

Table 15 Clinical results classified by causative organisms

\begin{tabular}{|c|c|c|c|c|c|}
\hline \multirow{2}{*}{ Microorganism } & \multicolumn{4}{|c|}{ No. of Patients } & \multirow{2}{*}{ Total } \\
\hline & Excellent & Good & Fair & Poot & \\
\hline S. pneumoniae & & 5 & 1 & & 6 \\
\hline K. pneumoniae & & 1 & & & 1 \\
\hline K. oxytoca & & & 1 & & 1 \\
\hline K. ozaenae & & 1 & & & 1 \\
\hline E. cloacae & & & 1 & & 1 \\
\hline H. influenzae & & & 1 & & 1 \\
\hline H. influenzae + & 1 & & & & 1 \\
\hline \multicolumn{6}{|l|}{ K. pneumoniae } \\
\hline S. aureus + & & & 1 & & 1 \\
\hline \multicolumn{6}{|l|}{ P. mirabilis } \\
\hline Total & 1 & 7 & 5 & 0 & 13 \\
\hline
\end{tabular}


$5)$.

6）原因菌別細菌学的効果

S. pneumoniae が検出された 6 例では 4 例が消 失したが 2 例では菌交代がみられた。菌交代の Case 36 は気管支拡張症に併発した肺炎で $K$. pneumoniae に交代したが臨床的には有効であっ た. Case 49 のびまん性沉細気管支炎の急性増悪 では P. aeruginosaに菌交代し，臨床的にはやや 有効であった。 その他の菌種では E. cloacae が減 少にとどまった以外はすべてが消失した。しかし， 最初常在菌のみであったが, CFX 投与中に有意菌 が検出された症例が 2 例認められた. Case 17は一 次性肺炎で $P$. aeruginosa が検出されたが臨床的 には著効, Case 53はびまん性沉細気管支炎で $E$. agglomerans が検出されたが臨床的には有効で あった. (Table 16).

7）他剂無効例に対する臨床効果

他剂が無効で本剂に変更した11症例の臨床効果 は, 著効 1 例, 有効 6 例, やp有効 2 例, 無効 2 例であり有効率は $63.6 \%$ であった。疾患別では， 一次性肺炎 5 例では著効 1 例, 有効 3 例, 無効 1 例で有効率 $80.0 \%$, 二次性肺炎 2 例では有効 1 例, 無効 1 例で有効率 $50.0 \%$, 慢性気道感染症急性増 悪 4 例では有効 2 例，やや有効 2 例で有効率は 50.0\%であった.（Table 17）.

前投与抗生剂別の臨床効果では, macrolide 系 抗生剂無効 2 例抒よび penicillin 系抗生剂無効 2 例に対してはいずれも CFX 投与が著効もしくは

Table 16 Bacteriological results

\begin{tabular}{|c|c|c|c|c|c|}
\hline \multirow{2}{*}{ Microorganism } & \multicolumn{4}{|c|}{ No. of Patients } & \multirow{2}{*}{ Tota } \\
\hline & Eradicated & Decreased & Unchanged & Replaced & \\
\hline S. pneumoniae & 4 & & & 2 & 6 \\
\hline K. pneumoniae & 1 & & & & 1 \\
\hline K. oxytoca & 1 & & & & 1 \\
\hline K. ozaenae & 1 & & & & 1 \\
\hline E. cloacae & & 1 & & & 1 \\
\hline H. influenzae & 1 & & & & 1 \\
\hline \multicolumn{6}{|l|}{ H. influenzae +} \\
\hline K. pneumoniae & 1 & & & & 1 \\
\hline \multicolumn{6}{|l|}{ S. aureus +} \\
\hline P. mirabilis & 1 & & & & 1 \\
\hline Normal flora & & & & 2 & 2 \\
\hline Total & 10 & 1 & 0 & 4 & 15 \\
\hline
\end{tabular}

Table 17 Clinical results classified by diagnosis of patients who did not respond to other conventional antibiotic treatment

\begin{tabular}{|c|c|c|c|c|c|c|}
\hline \multirow{2}{*}{ Diagnosis } & \multicolumn{5}{|c|}{ No. of Patients } & \multirow{2}{*}{$\begin{array}{l}\text { Efficacy } \\
\text { Rate (\%) }\end{array}$} \\
\hline & Total & Excellent & Good & Fair & Poor & \\
\hline Primary Pneumonia & 5 & 1 & 3 & & 1 & 80.0 \\
\hline Secondary Pneumonia & 2 & & 1 & & 1 & 50.0 \\
\hline $\begin{array}{l}\text { Acute Exacerbation of } \\
\text { Chronic Bronchial Tract } \\
\text { Infection }\end{array}$ & 4 & & 2 & 2 & & 50.0 \\
\hline Total & 11 & 1 & 6 & 2 & 2 & 63.6 \\
\hline
\end{tabular}


Table 18 Clinical results classified by antibiotics used prior to CFX

\begin{tabular}{|c|c|c|c|c|}
\hline \multirow{2}{*}{ Previous Antibiotics } & \multicolumn{4}{|c|}{ Response to Cefoxitih } \\
\hline & Excellent & Good & Fair & Poor \\
\hline Josamycin & & 1 & & \\
\hline Clindamycin & & 1 & & \\
\hline Sulbenicillin & 1 & & & \\
\hline Piperacillin & & 1 & & \\
\hline Cephalexin & & 2 & & \\
\hline Cefatrizine & & & & 1 \\
\hline Cefmetazole & & & & 1 \\
\hline Latamoxef & & 1 & & \\
\hline Ceftezole + Tobramycin & & & 1 & \\
\hline Piperacillin + Gentamicin & & & 1 & \\
\hline Total & 1 & 6 & 2 & 2 \\
\hline
\end{tabular}

有効であった, cephem 系抗生剂無効 5 例は, 有効 3 例, 無効 2 例であった. cephem 系抗生剂と aminoglycoside 系抗生剂の併用，および penicillin 系抗生剂之 aminoglycoside 系抗生剂の併用 が無効であった症例では CFXはともにやや有効 であった．前投与抗生剤の投与経路別では，経口 剂無効 5 例での有効率は $80.0 \%$ あ゙あ，注射剂無 効 6 例の有効率は $50.0 \%$ でった（Table 18）.

数例の症例を呈示する.

Case 12, 一次性肺炎 (34歳, 男性) 初診約17日 前より感冒様症状あり, 某医にて clindamycin $600 \mathrm{mg}$ の投与を受けていた。 約 6 日前より再び発 熱, 咳, 関節痛が増強し, 続けて clindamycin の 投与を受けていたが胸部レ線像にて浸潤影出現し 入院となる. 入院時, 白血球数 $9,000, \operatorname{CRP}(3+)$, 血沈 1 時間值69mm であった. CFX 1 日 $4 \mathrm{~g}$ に て治療を開始し 6 日後には下熱し，14日間使用に よって胸部陰影改善, 白血球数 $4,900, \mathrm{CRP}(-)$, 血沈 1 時間値 $6 \mathrm{~mm}$ となり有効と判定した。喀痰 は経過中ほとんど喀出されず原因菌は不明であっ た。

Case 41. 二次性肺炎 (83歳，女性) 陳旧性肺結 核に合併した肺炎である。入院約 3 週間前より発 熱をきたし，某医にて治療を受け一時改善した。 1 週間前より再び発熱, 咳, 呼吸因難をきたし, latamoxef 1 日 $2 \mathrm{~g} 7$ 日間の投与を受けたが改 善せず入院となる. 入院時, 白血球数 $10,200, \mathrm{CRP}$
$(3+)$, 血液ガスは $\mathrm{PaO}_{2} \quad 52 \mathrm{mmHg}, \quad \mathrm{PaCO}_{2}$ $55 \mathrm{mmHg}$ を示し, 陳旧性肺結核に併発した肺炎に よる呼吸不全状態であった.CFX 1 日 $4 \mathrm{~g}$ にて治 療を開始し10日後に下熱し，14日間投与により白 血球数 $5400, \mathrm{CRP}$ (一) と改善し，また胸部レ線 像も陳旧性肺結核陰影のみとなり有効と判定し た。喀疢からは常在菌のみが検出され原因菌は不 明であった。

Case 51. びまん性汎細気管支炎急性増悪 (54歳, 男性)

びまん性汎細気管支炎で外来通院中であった が，入院約40日前より喀痰が膿性となり， josamycin 1 日1.2 g 39日間の投与を受けていた。 しかし喀痰の性状変らず，また 2 日前より発熱， 呼吸困難が増強し入院となる。入院時, 白血球 10,500, CRP $(2+)$ であり, CFX 1 日 $4 \mathrm{~g}$ にて 治療を開始し，翌日下熱，14日間投与にて，白血 球 $4,700, \mathrm{CRP}($ ）となった。 また喀痰量の減少 はみられなかったが，膿性から粘性へと改善がみ られたので有効と判定した。喀疢からは常在菌の みが検出され原因菌は不明であった。

なお， 2 例の無効例は次の項で紹介する.

\section{8）無効例の検討}

やや有効と判定した10例は，有効率算定に際し て有効とはみなさなかったが，全症例とも CFX 中止後, 他の抗生剂を使用せずに改善がみられて いる. 
$\mathrm{CFX}$ 無効例は 3 例みられ以下その症例につい て述べる.

Case 7. 一次性肺炎（57歳，女性）

胃潰瘍にて入院治療中発熱をきたし，CRP $(6+)$, 血沈 1 時間值 $128 \mathrm{~mm}$, 胸部レ線像にて右 下肺野に浸潤影がみられ肺炎と診断した。CFX 1 日 $4 \mathrm{~g}$ 投与を 4 日間継続したが $38^{\circ} \mathrm{C} \sim 39^{\circ} \mathrm{C}$ の発 熱が持続した為, 本剤無効と判定した。その後 minocycline 1 日200mg に変更し, 下熱, 症状の 改善がみられた。マイコプラズマ肺炎を疑っての 選択であったが，発生10日後の寒冷凝集反応， 、 イコプラズマ反応は上昇がみられなかった。

Case 15。一次性肺炎（88歳，女性）

体重 $26 \mathrm{~kg}$ で高血圧症および脳動脈硬化症の基 礎疾患がある。発熱，咳，胸部レ線像の浸潤影よ り肺炎と診断され，某医で cefmetazole 1 日 $2 \mathrm{~g}$ 投与を 21 日間受けていたが症状改善せず紹介入院 となる。院時, 白血球数, $7,400, \mathrm{CRP}(6+)$, 血沈 1 時間值 $124 \mathrm{~mm}$ であった。体重が少ないこ とから CFX 1 日 $2 \mathrm{~g}$ とし 9 日間投与したが下熱 せず，白血球数，11,700, $\operatorname{CRP}(6+)$, 血沈 1 時間 值 $127 \mathrm{~mm}$ 胸部レ線像の改善もみられず本剂無効 と判定した。その後 ceftizoxime 1 日 $2 \mathrm{~g}$ に変更 したところ下熱し,胸部レ線像の改善がみられた。 症状は重篤で自力で喀痰排出ができず原因菌検索 はできなかった。

Case 28. 二次性肺炎 (75歳, 男性) 入院 8 日前 より発熱, 呼吸困難, 咳, 喀痰あり某医にて cefatrizine 1 日 $1 \mathrm{~g}$ の投与を 6 日間受けていたが症状 改善せず入院となる，入院時，白血球数 8,300 , $\mathrm{CRP}(5+)$, 血沈 1 時間值 $74 \mathrm{~mm}$, 胸部レ線像にて 浸潤影がみられ肺炎と診断，心不全子併発してお りジギタリス剤投与を行いながら CFX 1 日 $4 \mathrm{~g}$ を10日間投与したが，発熱は持続し，白血球数 $10,600, \operatorname{CRP}(6+)$, 血沈 1 時間值 $90 \mathrm{~mm}$ を示し, 胸部レ線像も改善せず本剂無効と判定した。 その 後 cefotaxime 1 日 $2 \mathrm{~g}$ に変更し症状の改善を認 めた。

9) 副作用

副作用として 1 例に発疹がみられたので呈示す る.
Case 35.73歳，男性，慢性気管支炎に併発した 二次性肺炎．本剂 1 日 $4 \mathrm{~g} 2$ 分割投与 7 日目頃よ り発疹出現，しだいに増強し，9 日目に投与中止 した。発疹に対しとくに処置は行わず約 1 週間の 経過で改善した。な和臨床的には有効であった。

本剂投与が関連したと考党られる臨床検査値異 常は 7 例にみられたので呈示する。

Case 17.42歳，男性，一次性肺炎，本剂 1 日 4 g 2 分割投与. 投与前 Al-p 6.1U (KA) であった が，投与 8 日目 Al-p 35U(KA) に上昇した。12日 間投与後 5 日間休薬, 投与再開 3 日目 Al-p 14U (KA) と正常であり一過性の上昇であった.

Case 21. 32歳，女性，一次性肺炎. 本剤 1 日 4 g 2 分割 14 日間投与, 投与前 GOT 13IU, 投与 8 日 目 GOT 38IU, 投与終了時 GOT 47IU と軽度の上 昇がみられた。本剤中止 2 週間後にはGOT $26 I U$ と正常に復した.

Case 33. 71歳, 男性, 肺気腫に併発した二次性 肺炎. 本剂 1 日 $4 \mathrm{~g} 2$ 分割14日間投与. 投与前 GOT 29IU，投与終了時 GOT 51IU と軽度の上昇 がみられた。本剤中止 1 週間後には GOT 38IU と 正常に復した。

Case 34.76歳，男性，肺気腫に併発した二次性 肺炎. 本剂1日 $4 \mathrm{~g} 2$ 分割 14 日間投与. 投与前白血 球数 11,600 が投与終了時白血球数 2,700 に減少し た。本剤中止 5 日目には血球数 3,500 に改善した。

Case 39. 68歳，女性，肺線維症に併発した二次 性肺炎。本剂 1 日 $4 \mathrm{~g} 2$ 分割14日間投与. 投与前 白血球数 13,300 が投与終了時白血球数 2,400 亿減 少した。本剤中止 12 日目白血球数 $3,100 ， 1$ 力月後 白血球数 3,400 亿改善した.

Case 54.67歳，女性，陳旧性肺結核に伴う気管 支拡張症が原因の慢性気道感染症急性増悪。本剂 1 日 $4 \mathrm{~g} 2$ 分割 13 日間投与. 投与前 GOT 21IU, BUN $15.5 \mathrm{mg} / \mathrm{dl}$, 投与終了時 GOT 43IU, BUN $22.9 \mathrm{mg} / \mathrm{dl}$ と軽度の上昇がみられた。本剂中止 4 カ月後には GOT $16 \mathrm{IU}, \mathrm{BUN} 10.7 \mathrm{mg} / \mathrm{dl}$ と正常 に復した。

Case 58. 82歳, 女性, 効果判定除外例. 本剂 1 日 $4 \mathrm{~g} 2$ 分割 7 日間投与. 投与前 BUN $17 \mathrm{mg} / \mathrm{dl}$, creatinine $1.1 \mathrm{mg} / \mathrm{dl}$ が投与 3 日目 BUN $29 \mathrm{mg} /$ 
Table 19 Adverse reaction and abnormal laboratory findings

\begin{tabular}{lcc}
\hline Adverse Reaction & $\begin{array}{c}\text { No. of } \\
\text { Patients }\end{array}$ & Case No. \\
\hline Skin Eruption & 1 & 35 \\
Elevation of S-GOT & 2 & 21,33 \\
Elevation of S-GOT, BUN & 1 & 54 \\
Elevation of BUN, & 1 & 58 \\
Elevation of Al-P & 1 & 17 \\
Leukopenia & 2 & 34,39 \\
\hline Total & 8 & \\
\hline
\end{tabular}

Table 20 Evaluation of usefulness

\begin{tabular}{lc}
\hline \multicolumn{1}{c}{ Usefulness } & No. of Patients \\
\hline Markedly useful & 9 \\
Moderately useful & 29 \\
Slightly useful & 13 \\
Not useful & 4 \\
\hline
\end{tabular}

dl creatinine $1.4 \mathrm{mg} / \mathrm{dl}$, 投与終了時 BUN $39 \mathrm{mg} /$ $\mathrm{dl}$, creatinine $1.7 \mathrm{mg} / \mathrm{dl}$ に上昇した。投与中止 2 週間後にはBUN $25 \mathrm{mg} / \mathrm{dl}$, creatinine $1.2 \mathrm{mg} / \mathrm{dl}$ と改善がみられた（Table 19）.

なお, 全例に皮内反応を施行し, 全例陰性であっ た. また，投与前後にクームステストを施行した 症例は25例であるが， 1 例本剂投与前直接クーム ステスト（十）が投与後 $(2+)$ に増強した (Case 10）以外はすべて投与前後共に陰性であった。

10）有用性

副作用を考慮した CFX の有用性を Table 20に 示した。かなり有用以上は 55 症例中 38 症例 $69.1 \%$ であった。

\section{総括ならびに考案}

近年の抗生剂の開発は $\beta$-lactam 系, とくにcephem 系抗生物質が中心であり, 新 cephem 系抗 生剂が続々と市販されてきている. cephem 系抗 生剂はその開発年次, $\beta$-lactamase に対する安全 性, 抗菌スペクトラムなどから第一世代，第二世 代，第三世代などの世代別に分類されることがあ る ${ }^{6)}$. 第三世代の cephem 系抗生剂はグラム陰性 桿菌に対する抗菌力の強化および広範囲な抗菌ス
ペクトラムにより compromised host の感染症に 対する治療に多くの期待がかけられている。しか し一方では第三世代の cehem 系抗生剂を中等症 以下の感染症に第一選択として使用することに対 しては多くの警告がされて拉り，あらためて第一 世代の cephem 系抗生剂の存在意義が注目されて いる7).

今回，私共が臨床治験した CFX は第二世代の cephem 系抗生剂に属し，その抗菌力拈よび抗菌 スペクトラムは第一世代と第三世代の中間に位置 する抗生剤である。呼吸器感染症に対する効果が 全国レベルで検討評価され5)すでに 6 年を経過し ている. 今回，再評価を目的として名古屋市立大 学第一内科拈よび関連病院の 7 施設に拈いて臨床 治験を施行した。期間は昭和56年12月から昭和 57 年 3 月の 4 カ月間である.

本治験に扔いて CFX が投与された症例は合計 66例であるが，小委員会にて11例を効果判定の対 象から除外した。除外例は重篤な基礎疾患のため 死亡, 前投薬によりかなりの改善, 感染が不明か または上気道感染の夕, 主治医が途中で投与中止, 原因菌が P. aeruginosa, steroid の併用, 後に結核 症と判明などの症例で, 効果判定の対象としたも のは55例であった。副作用は重篤な基礎疾患で死 亡した 2 例と，検査が不備であった 1 例を除いた 63例について検討した。

臨床成績を総括するとすでに述べた如く，有効 以上は 55 例中 42 例であり， $76.4 \%$ の有効率であっ た。これは第25回日本化学療法学会総会に打ける シンポジゥム「cefoxitinの評価」での有効率より 高い成績であった。呼吸器感染症の種類別での有 効率は一次性肺炎 $84.6 \%$, 二次性肺炎 $68.8 \%$, 慢 性気道感染症急性増悪 $69.2 \%$ であり, 呼吸器に基 礎疾患のある群の有効率は低值を示したが, 基礎 疾患がないか，または呼吸器感染とは結びつかな い基礎疾患を有する症例の肺炎では高い有効率が 得られた。重症度別にみた臨床効果は軽症 $90.9 \%$, 中等症 $76.3 \%$, 重症 $50.0 \%$ の有効率であり, 重症 度に比例して有効率の低下がみられた. 総投与量 と臨床効果之の関係は, $21 \mathrm{~g} \sim 40 \mathrm{~g}$ 投与の有効率が $77.8 \%$ であるのに対し, $41 \mathrm{~g} \sim 60 \mathrm{~g}$ 投与では $86.5 \%$ 
であり総投与量の増加により有効率の上昇が期待 できる結果であった。一方, $61 \mathrm{~g}$ 以上の投与では有

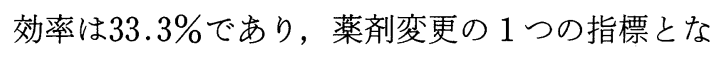
ると考えられた。年齢からみた有効率は 69 歳以下 $82.8 \% ， 70$ 歳以上 $69.2 \%$ 之高齢者に打いて有効率 が低く, 感染症に拈ける年齢因子の重要性が示唆 された。

原因菌を推定することができた症例は13症例 で, その臨床効果はS. pneumoniae が原因菌の 6 例では 5 例が有効例であった。一方, 種々のグラ ム陰性桿菌が原因菌であった 7 例では有効率が 3 例と少なかった。しかし細菌学的効果では $S$. pneumoniae 6 例中 2 例に菌交代が夕られたが,

7 例のグラム陰性桿菌では減少にとどをった 1 例 を除きすべてが消失した，本剤の特徵としてグラ ム陰性桿菌に対する優れた抗菌力があげられてお り, これが細菌学的効果に反映されたものと思わ れるが, 臨床的にはやや有効にとどまる症例が多 かった。

他剂無効例に対する $\mathrm{CFX}$ の臨床効果は11例で 検討され $63.6 \%$ の有効率を得た。疾患別での有効 率は一次性肺炎は $80.0 \%$ であが，二次性肺炎お よび慢性気道感染症急性増悪では共に $50.0 \%$ と有 効率が低下している. 前投与抗生剂では macrolide系执よび penicillin系抗生剂無効例に対 してすべて良好な効果を示している。また。経口 抗生剂無効例に対しては $80.0 \%$ の有効率であっ た。逆に, 前投与抗生剂が cephem 系抗生剂の場 合，扣よび注射剤の場合には有効率は低值であっ た。以上, CFX は macrolide 系扢よび penicillin 系抗生剂無効の一次性肺炎に対し二次選択薬とし て有用であると考えられた。

$\mathrm{CFX}$ 無効例は 3 例にみられ, 本剂中止後 minocycline, ceftizoxime, cefotaxime がそれぞ れ有効であった. minocycline 有効例は57歳の一 次性肺炎であり, 寒冷凝集反応およびマイコプラ
ズマ反応は発症後10日目までしか追跡されていな いので確診は得られていないが，マイコプラズマ 肺炎の可能性が高いと考えている. ceftizoxime および cefotaxime 有効例はそれぞれ脳動脈硬化 症を基礎にもつ88歳の一次性肺炎患者之心不全を 合併した75歳の二次性肺炎患者である. 両者とも 重症例であった。CFXが無効な compromised hostの肺炎に対して第三世代の cephem 系抗生 剂が有用であった。

副作用として発疹が 1 例みられた。臨床検査值 異常としてGOT 上昇 2 例, GOT, BUN 上昇 1 例, BUN, creatinine 上昇 1 例, $\mathrm{Al}-\mathrm{p}$ 上昇 1 例, 白血球減少症 2 例みられたがいずれも本剤中止あ るいは終了後, 正常に復している。

\section{文献}

1) Miller, A.K., Cellozzi, E., Kong, Y., Pelak, P.A., Hendlin, D. \& Stapley, E.O.: Cefoxitin, a semisynthetic cephamycin antibiotic: In vivo evaluation. Antimic Agents \& Chemoth., 5(1): 33-37, 1974.

2）五島瑳智子, 小川正俊, 金子康子, 辻 明良, 桑 原章吾：セファマイシン系広域抗菌薬 Cefoxitin とセファロスポリン系抗菌薬の基礎的評価. Chemotherapy, 26 (S-1) : 26-40, 1978.

3） (故) 中沢昭三, 戸辺建介, 平井芳美, 山岡 暢, 大崎節子, 高井かずみ, 西野武志: 新セファマイ シン抗生物質 Cefoxitin に関する細菌学的研究. Chemotherapy, 26 (S-1) : 41-63, 1978.

4）三和敏夫, 望月 泉, 江崎孝行, 甲畑俊郎, 今村 博務, 小林とよ子, 渡辺邦友, 二宮敬宇, 上野一 恵, 鈴木祥一郎：Cefoxitin の嫌気性菌に対する 抗菌作用. Chemotherapy, 26 (S-1): 71-77, 1978.

5）第25回日本化学療法学会総会：新薬シンポジゥム 「Cefoxitin の評価」. 岐阜市, 1977.

6）西田 実：特集・抗生物質の新しい使い方一最近 注目されている新しい抗生物質一セファロスポリ ン系薬剤. 小児科診療, $44: 853-861,1981$.

7）島田 馨：特集・第三世代の抗生物質. 各科領域 に抢ける抗生物質の将来一内科一. 日本臨床, 39 : 58-65, 1981. 


\author{
Clinical Evaluation of Cefoxitin in Respiratory Tract Infections \\ Masahito KATO, Toshihiko TAKEUCHI, Makoto ITO, Kunio NANJO \& Joichi KATO \\ The First Department of Internal Medicine, Nagoya City University, School of Medicine \\ Toshiyuki YAMAMOTO \& Mikizo SUZUKI \\ Nagoya Koseiin Geriatric Hospital \\ Saburo KITAURA, Kazuo YOSHITOMO \& Motoko YAMAMOTO \\ Department of Internal Medicine, Nagoya Higashi Municipal Hospital \\ Hidekazu HANAKI \& Masao KOZUKA \\ Department of Internal Medicine, Nagoya City Johsai Hospital \\ Naohiko TERAO \& Hideaki YAMADA \\ Department of Internal Medicine, Nagoya Midori Municipal Hospital \\ Kiyoshi YOKOCHI \& Etuo OKUYAMA \\ Department of Internal Medicine, Chita General Hospital \\ Hirohiko NAGASAKA \\ Department of Internal Medicine, Owari Prefectural Hospital
}

Cefoxitin was administered to a total of 66 patients with various respiratory tract infections and the following results were obtained:

1) Out of 55 patients who were clinically evaluated, 42 patients $(76.4 \%)$ showed excellent and good responses.

2) The efficacy rate classified by diagnosis was $84.6 \%$ for primary pneumonia, $68.8 \%$ for secondary pneumonia and $69.2 \%$ for acute exacerbation of chronic bronchial tract infection.

3 ) The efficacy rate classified by severity of illness was $90.9 \%$ for mild cases, $76.3 \%$ for moderate cases and $50.0 \%$ for severe cases.

4) The efficacy rate classified by age was $82.8 \%$ for patients younger than 69 years and $69.2 \%$ for patients older than 70 years.

5) Causative organisms were isolated in 13 patients. These organisms were eradicated in 10 patients, decreased in number in one patient and replaced by other organisms in 2 patinens. In these 2 patients normal flora was replaced by othr organisms during the course of treatment. The organisms that emerged were $P$. aeruginosa ( 2 cases), E. agglomerans ( 1 case) and $K$. pneumoniae ( 1 case).

6) A total of 11 patients who failed to respond to other conventional antibiotic treatment were treated with cefoxitin and seven patients $(63.6 \%)$ showed excellent and good responses.

7) Out of 55 patients who were clinically evaluated, 3 patients failed to respond to cefoxitin. The first patient was successfully treated with minocycline, the second with ceftizoxime and the third with cefotaxime.

8) Side effects were observed in 8 out of 63 patients. These were skin eruption (1), elevation of SGOT (2), elevation of SGOT and BUN (1), elevation of BUN and creatinine (1), elevation of Al-p (1) and leukopenia (2). 